\title{
A magyar határ menti nagyvárosok határon átnyúló kormányzásának vizsgálata az EGTC-kben és INTERREG- projektekben betöltött szerepük alapján
}

\author{
Governance characteristics of big cities in border regions of \\ Hungary based on their role in EGTCs and INTERREG projects
}

\author{
FEKETE DÁVID
}

FEKETE Dávid: egyetemi adjunktus, Széchenyi István Egyetem Regionális-tudományi és Közpolitikai Tanszék; 9026 Győr, Egyetem tér 1.; fdavid@sze.hu; https://orcid.org/ 0000-0002-8097-2496

KULCSSZAVAK: nagyvárosi kormányzás; határ menti együttműködés; európai területi együttműködési csoportosulás; INTERREG; többszintű kormányzás

ABSZTRAKT: Napjainkban a nagyvárosok egyre fontosabb szerepet játszanak az európai területi politikában. A nagyvárosok kormányzása már rég nem kizárólagos feladata a helyi önkormányzatnak; a kormányzásban résztvevők köre folyamatosan bővül, továbbá a nagyvárosok térségükkel együtt élnek, s ezek a vonzáskörzetek országhatárokat is átléphetnek.

Jelen tanulmány fókuszában a határ menti magyarországi nagyvárosok kormányzási gyakorlatának vizsgálata áll. A tanulmányban azonos szempontok szerint elemzett hat, 100000 fő feletti nagyváros: Győr, Pécs, Szeged, Debrecen, Miskolc és Nyíregyháza. Ezek a városok a határ közelében fekszenek, sok esetben természetes régióközpontként tartja számon őket a határon túli területek lakossága is. A nagyvárosok határon átnyúló kormányzási hatásait két dimenzióban elemezzük. Egyrészt a nagyvárosok formalizált, határon átnyúló területi együttműködési szervezetben való részvételét vizsgáljuk, ennek indikátora valamely európai területi együttműködési csoportosulásban (EGTC) betöltött szerep. A második vizsgálati dimenziót a határon átnyúló projektek megvalósításában való részvétel jelenti, indikátorként a hat nagyváros jelenleg is folyamatban lévő INTERREG projektjei szolgálnak.

Noha megfelelő feltételrendszerek alakultak ki, nagyvárosaink többsége mégsem él a lehetőségekkel. A vizsgálat bizonyította, hogy az első indikátorként kiválasztott EGTC tagság mindössze a vizsgált nagyvárosok felében áll fenn, ezek közül valódi aktivitást mindössze két nagyváros (Pécs és Győr) mutat. A projektalapú együttműködéseket vizsgálva pusztán három olyan projekt van, mely határ menti térségben valósul meg, s azok két nagyvároshoz (Győr és Szeged) kötődnek. A határ menti kormányzási struktúrák kiépítésében a vizsgált hat nagyvárosból kettő (Miskolc, Debrecen) semmilyen tevékenységet nem mutat a meghatározott indikátorok alapján, Nyíregyháza esetében a formális keret ugyan létrejött, de valódi aktivitás nem tapasztalható.

Dávid FEKETE: assistant professor, Department of Regional Studies and Public Policy, Széchenyi István University; Egyetem tér 1., H-9026 Györ, Hungary; fdavid@sze.hu; https://orcid.org/00000002-8097-2496

KEYWORDS: metropolitan governance; cross-border cooperation; European Grouping of Territorial Cooperation; INTERREG; multi-level governance

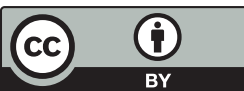


ABSTRACT: Big cities are playing an increasingly important role in European spatial policy nowadays. Governing big cities is no longer the sole responsibility of local governments; the number of actors (civic organizations, stakeholders, universities, economic actors, companies etc.) involved in governance is constantly expanding. Moreover, big cities cohabit with their agglomerations, that may as well cross national borders.

The aim of this paper is to examine the governance practices of big Hungarian cities in border regions through the analysis of six cities with over 100,000 inhabitants: Györ, Pécs, Szeged, Debrecen, Miskolc and Nyíregyháza. These cities are located in border regions, and in many cases are also considered a natural regional center by the population of the cross-border areas. The crossborder governance effects of the examined cities are analyzed in two dimensions: participation of large cities in a formalized cross-border territorial cooperation organization, such as the European Grouping of Territorial Cooperation (EGTC), and participation in the implementation of crossborder projects, where indicators are the ongoing INTERREG projects of the six cities. Our findings indicate that although the appropriate institutional framework has been developed, most of these Hungarian cities do not use their opportunities. Only half of the examined large cities have EGTC membership but two large cities (Pécs and Györ) show real activity.

The examination of project-based collaborations indicated only three implemented projects in the border area connected to two cities (Györ and Szeged). In terms of cross-border governance structures, two (Miskolc, Debrecen) of the six large cities do not show any activity while in the case of Nyiregyháza the formal framework has been established, but no real activity could be traced. The study argues that Hungarian big cities need to place more emphasis on strengthening their cross-border governance, organizing and coordinating their natural surroundings in the future. It is necessary to establish multi-stakeholder, functioning EGTCs in the border regions, to identify and involve key partners across the border, and to identify the common development needs of the border region.

\section{Bevezetés}

Napjainkban a nagyvárosok egyre fontosabb szerepet játszanak az európai területi politikában, ezt a szerepüket a regionális tudományok szakértői jó ideje vizsgálják, figyelik a nagyvárosok helyzetének alakulását, fejlődési pályáit. Mivel Európában a nagyvárosok egyre meghatározóbbak mind gazdasági teljesítményük, mind pedig népességkoncentráló képességük alapján, az elmúlt évtizedekben a regionális tudományok terén zajló kutatások, diskurzusok kedvelt témáivá váltak. A városkutatás „divatja” itthon is teret hódított a 2000-es években.

A nagyvárosok elemzése számtalan dimenzióban került a regionális tudományi kutatások homlokterébe, ezek egyik fontos csoportja a nagyvárosok kormányzásával foglalkozik. Az európai városfejlődési trendek a nagyvárosi kormányzás területén az utóbbi időben két irányba mutatnak:

- A nagyvárosok kormányzása már rég nem kizárólagos feladata a helyi önkormányzatnak, a kormányzásban résztvevők köre folyamatosan bővül, egyre több új szereplő lép be a politikacsinálás e mezőjébe: gazdasági szereplők, civil szervezetek, felsőoktatási intézmények stb.

- A nagyvárosok hatása, kormányzási potenciálja nem áll meg a település közigazgatási határainál: a nagyvárosok térségükkel együtt élnek, a településüket körülvevő vonzáskörzetből napi szinten ingáznak az emberek, a 
vonzáskörzetben létrejöhetnek kisebb alközpontok (policentrikus városrégió koncepciója), ráadásul ezek a vonzáskörzetek országhatárokat is átléphetnek.

Jelen tanulmány fókuszába a magyarországi határ menti nagyvárosok kormányzási gyakorlatának vizsgálata áll, figyelemmel a fent felvázolt két meghatározó trendre. A kutatás kérdései a következők:

1. A határ menti magyar nagyvárosok kormányázásának léteznek-e formalizált intézményi keretei?

2. A magyar nagyvárosok együttműködnek-e intézményesített formában határon túli vonzáskörzetük településeivel, szervezeteivel?

3. Léteznek-e olyan projektjellegű együttműködések, melyek erősítik a határ menti nagyvárosok kormányzási tevékenységét?

4. Milyen mértékben vesznek részt a határ menti projektekben a nem kormányzati szereplők?

A vizsgálati körbe hat nagyváros került. Ismert, hogy a regionális tudományok hazai művelői rendre szembesülnek a magyar településhálózat aránytalanságaival, azzal a szembetűnő helyzettel, hogy óriási szakadék tátong a fơváros és a népességszámban Budapestet követő Debrecen között (a fóváros lakossága közel tízszerese a második legnépesebb városénak). Mivel az első világháború után a magyar városhálózat fontos és fajsúlyos alkotóelemeinek nagy része a trianoni határokon kívül rekedt, továbbá az 1950-es években megvalósult a „Nagy-Budapest” koncepció, a XX. század második felére ez az aránytalanság állandósult. Az 1. táblázatban láthatók az egyes településtípusok népességszám szerint, az ENSZ Demográfiai Évkönyve (United Nations 2016), továbbá a magyarországi gyakorlat alapján.

Látható, hogy a nemzetközi értelmezés szerint Magyarország egy metropolisszal rendelkezik, nagyvárosi kategóriába eső települése ugyanakkor nincs. Hazai viszonylatban viszont a nagyvárosi kategóriába soroljuk a 100 ezer és 1 millió fó közti lakosságszámú városokat. Ennek oka, hogy bizonyos regionális központi feladatokat ezek a városok látnak el hazánkban, többen közülük jelentős agglomerációval, vonzáskörzettel rendelkeznek és a magyar városhálózat jelentős elemeinek számítanak (Rechnitzer 2019). A tanulmányban azonos szempontok

1. táblázat: Az egyes településtípusok népességszám alapján Settlement types by population

ENSZ Demográfiai Évkönyv

Magyarország

\begin{tabular}{lll}
\hline Metropolisz & 1 millió lakos fölött & 1 millió lakos fölött \\
Nagyváros & 500 ezer és 1 millió lakos között & 100 ezer és 1 millió lakos között \\
Középváros & 100 ezer és 500 ezer lakos között & 20 ezer és 100 ezer lakos között \\
Kisváros & 20 ezer és 100 ezer lakos között & 5 ezer és 20 ezer lakos között \\
Község & & 5 ezer lakos alatt \\
\hline
\end{tabular}

Forrás: Saját szerkesztés a terport.hu (2018) alapján 
szerint elemzett hat, 100 ezer fő feletti nagyváros: Győr, Pécs, Szeged, Debrecen, Miskolc és Nyíregyháza. ${ }^{1}$

A tanulmány elsősorban a határ menti magyar nagyvárosokkal kapcsolatos intézmények, határon átívelő európai uniós projektek elsődleges adatainak gyüjtésével és elemzésével készült.

\section{A nagyvárosi kormányzás evolúciója}

A nagyvárosok fejlödése, különösen is kormányzási mechanizmusaik, módszereik az elmúlt években fontos szeletét képezték a regionális tudományi kutatásoknak, s a témában számos új eredmény született (lásd Balázs 2014; Faragó 2006; Fekete 2017a, c; Horváth M. 2012, 2015; Lefèvre 1998; Nelson-Foster 1999; Pálné 2008, 2015; Sybert 1999). A városrégiókat ma olyan funkcionális térként értelmezik, melyben egy vagy több városmag is található, körülöttük pedig agglomerációs és szuburbanizációs folyamatok zajlanak az urbanizációs folyamatok hatására (Somlyódyné 2011). A városok közigazgatási határai értelemszerüen nem esnek egybe funkcionális határaikkal, az azokat körbevevő agglomerációkban is jelentős népesség koncentrálódik, sűrűsödnek a gazdasági, szolgáltatási és kereskedelmi tevékenységek. A város és térsége problematikát többféle módon is megpróbálták már feloldani. A kezdeti időszakban (az 1800-as évek végétől 1945-ig) az európai városok egyszerűen bekebelezték a határaikon lévő ipar- és gyárvárosokat, azok a közigazgatási határon belülre kerültek. A II. világháborút követően az egyes országok kormányzati szinten ösztönözték vagy kényszerítették ki a nagyvárosi szintű igazgatási rendszereket, ám ezek a rendszerint bürokratikus szervezetek az újraelosztó regionális politika képviselőiként az 1980-as években megbuktak. Az endogén gazdasági fejlődés koncepciójának terjedése révén a nagyvárosok ekkor nyitottak a gazdasági és a civil szféra irányába. Napjainkban az önkéntes, elsősorban gazdaságfejlesztési fókusszal rendelkező, merev intézményi struktúrákat kerülő együttműködések korszakát éljük (Somlyódyné 2011). Ebben az időszakban a hálózatos kormányzás módszere terjed a nagyvárosokban (1. ábra), laza horizontális struktúrák jönnek létre (Somlyódyné 2008), gyakran kormányzati szereplők nélkül (Pálné 1999), sőt, az USÁ-ban gyakran az önkormányzatok nélkül (Oakerson 2004), a szereplők közti koordináció pedig ún. intézményi kollektív cselekvésen keresztül valósul meg (Feiock 2004). Az európai tapasztalatok azonban a városi szervezetek aktív közremúködését mutatják, sőt, előfordul, hogy a korábbi időszakok intézményes keretei a governance-típusú irányítással párhuzamosan ma is jelen vannak.

Ezeket az együttműködési rendszereket tartják a fejlődés zálogának az ún. innovációs folyamatmodellek is, így a széles körben ismert, a kormányzat - felsőoktatási intézmény - gazdasági szereplők együttműködésén alapuló Triple-Helixmodell (Etzkowitz, Leydesdorff 1996, 2000), illetve ennek civil szervezetekkel 
1. ábra: A hálózatos nagyvárosi kormányzás szereplői Actors of multi-level metropolitan governance

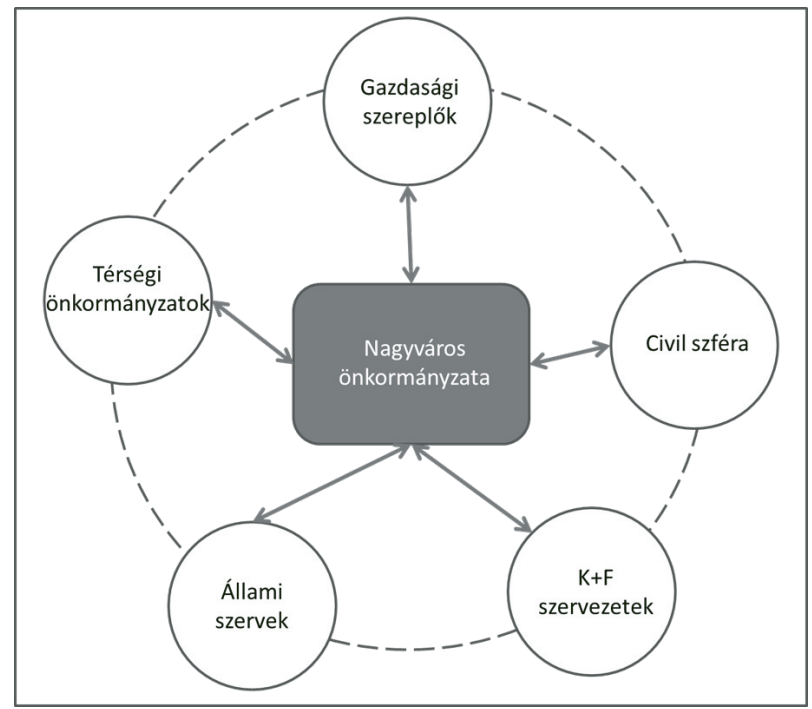

Forrás: Fekete 2017d, 26.

(Quadruple-Helix), továbbá környezeti szempontokkal (Quintuple-Helix) kibővített variációi (Carayannis, Campbell 2012; Carayannis, Barth, Campbell 2012; Vas 2012). Szintén a különböző szereplők együttműködésén alapulnak a városrezsimelméletek is, melyek lényege, hogy a helyi fejlesztéspolitika elsősorban a helyi érintettek bevonására fókuszál (Pálné 2010; Stone 1989; Stone, Sanders 1987). A helyi gazdaságfejlesztéssel foglalkozó szakértők is kiemelik annak jelentőségét, hogy a korábbi gyakorlatot (multinacionális vállalatok letelepítése, beágyazása, szűk döntéshozó kör) meghaladva az 1990-es évektől az üzleti és a civil szféra erőteljes partnersége érhető tetten a helyi gazdaság fejlesztésénél (Bajmócy 2011).

A nagyvárosi határ menti együttműködések esetében több szerző is kiemeli az európai területi együttműködési csoportosulások jelentőségét. A magyar-szlovák határ menti önkormányzati együttmüködések lehetőségét áttekintő elemzésből kiderül, hogy a kezdeti, nemzeti érzelmű együttműködéseket felváltották a projektalapú kooperációk, azonban az eltérő közigazgatási berendezkedés, a középszintek eltérő kompetenciái nehezítik a közös munkálkodást. Mindezek ellenére már a 2000-es évek első évtizedének végére kialakultak a stabilnak mondható, szolgáltatásokat szervező és állandó munkakapcsolatot biztosító együttműködések (Mezei, Tóth 2008). Konkrét elemzések születtek arról is, hogy egyes határ menti nagyvárosi régiókban milyen szerepet játszhatnak az EGTC-k. Egy győri esettanulmány megállapítja, hogy az Arrabona EGTC néhány változtatás után (pl. a tagság jelentős kibővítése, szakmai bizottságok alakítása) alkalmas lehetne a győri központú határon átnyúló térség folyamatainak szervezésére (Fekete 2017b). Heintel és szerzőtársai (2015) az Írottkő-Geschriebenstein természetvédel- 
mi terület példáján a regionális kormányzás szempontjából elemzik a határon átnyúló együttműködés lehetőségeit és korlátait, és megállapítják, hogy önmagában egy határon átnyúló természeti övezet léte nem jelent garanciát arra nézve, hogy kialakuljanak a közös szervezeti keretek a fejlesztésekhez szükséges források lehívására.

A 2. táblázatban a modern időszak gazdaságfejlesztése és a posztmodern időszak gazdasági kormányzásának különbségei olvashatók. A kormányzás-típusú együttmüködések ebben az esetben is a szereplői kör kibővítésével jártak együtt, az alulról felfelé történő beavatkozás látható, mely elsősorban keresletorientált és inkább a soft befektetésekre koncentrál.

Ráadásul azok a városok, melyek transznacionális vállalatokat tömörítenek, különleges helyzetben vannak, hiszen a náluk otthonra lelt nagyvállalatok révén bekapcsolódnak a globális logisztikai láncokba, így sokszor hazai városhálózatukból kilépve a globális városhálózat részévé válnak (Enyedi 2012). A vizsgált nagyvárosok közül legerőteljesebben Győr és Kecskemét érintett ezen a téren, hiszen jelentős járműipari vállalatoknak adnak helyet (Audi, Mercedes), továbbá a jövőben a BMW-gyárberuházás kapcsán minden bizonnyal Debrecen ilyen típusú pozícióinak erősödésével is számolni kell.

A többségében gazdasági megközelítésből kiinduló kormányzási modellek és módszerek mellett újabban előtérbe kerültek a szakirodalomban a kulturális kormányzással foglalkozó elemzések (Moon 2001; Schmitt 2011). Ennek oka, hogy a kulturális miliő alakítása, egy város kreativitásának kibontakoztatása szintén nem az önkormányzatok kizárólagos felségterülete, sokkal inkább egy széleskörű partnerségen alapuló folyamat. Ez a vetület Magyarországon is felértékelődött az elmúlt időszakban, hiszen a kutatás keretében vizsgált hat nagyváros közül három (Győr, Debrecen, Székesfehérvár) is pályázott a 2023-as Európa Kulturális Fővárosa ${ }^{2}$ címre.

2. táblázat: A modern gazdaságfejlesztés és a posztmodern gazdasági kormányzás beavatkozásai Intervensions of modern economic development and postmodern economic governance

\begin{tabular}{lll} 
& Modern gazdaságfejlesztés & \multicolumn{1}{c}{$\begin{array}{c}\text { Posztmodern gazdasági } \\
\text { kormányzás }\end{array}$} \\
\hline Beavatkozás filozófiája & Kínálatorientált & Keresletorientált \\
Beavatkozás fö eszközei & $\begin{array}{l}\text { Hard infrastruktúra } \\
\text { fejlesztése }\end{array}$ & $\begin{array}{l}\text { Soft befektetések, gazdasági } \\
\text { miliő alakítása }\end{array}$ \\
Beavatkozás iránya & Top-down & Bottom-up \\
$\begin{array}{l}\text { Beavatkozás } \\
\text { kedvezményezett } \\
\text { csoportjai }\end{array}$ & Gazdasági szereplők & $\begin{array}{l}\text { Gazdasági-, felsőoktatási-, } \\
\text { kutatás-fejlesztési } \\
\text { intézmények és szervezetek }\end{array}$ \\
\hline
\end{tabular}

Forrás: saját szerkesztés 


\section{A magyar nagyvárosok kormányzásának nemzetközi dimenziói}

A vizsgált hat nagyváros a magyar határ közelében fekszik, sok esetben természetes régióközpontként tartja számon őket a határon túli területek lakossága is. A nagyvárosok határon átnyúló kormányzási hatásait két dimenzióban vizsgáljuk. Egyrészt megnézzük, hogy a nagyvárosok közül melyek érintettek valamilyen formalizált, határon átnyúló területi együttműködési szervezetben. Ennek indikátora valamely európai területi együttmüködési csoportosulásban (EGTC) betöltött szerep. Egy ilyen formalizált együttműködés ugyanis sokat elárul a nagyváros szerepfelfogásáról: részt vesz-e ilyen együttműködésben? Amennyiben igen, képes-e abban vezető szerepet játszani? Mennyiben tudja irányítani a szervezet keretében zajló munkát? Képes-e hazai és határon túli vonzáskörzetében lévő településekkel közösen működtetni egy szervezetet? Ezekre a kérdésekre választ kaphatunk az érintett EGTC-k vizsgálatán keresztül.

A magyar nagyvárosok határon átnyúló kormányzási tevékenységének másik fontos fokmérője lehet, hogy milyen határon átnyúló projektek megvalósításában vesznek részt, azokban játszanak-e vezető szerepet? Milyen területek mentén alakítják ki együttműködéseiket? Milyen szereplői kört vonnak be a határon átnyúló projektek megvalósításába? Fenti kérdések megválaszolásához a hat nagyváros jelenleg is folyamatban lévő INTERREG projektjeinek elemzését hívjuk segítségül.

A nemzetközi dimenzió indikátoraként tehát az európai területi társulásokban való intézményesített megjelenés, továbbá az INTERREG projektben való részvétel került meghatározásra. (3. táblázat)

3. táblázat: A nagyvárosi kormányzás határ menti vetületének dimenziói és indikátorai Dimensions and indicators of metropolitan governance in cross-border regions

\begin{tabular}{ll} 
עımıerıı & ıпııкuıur \\
\hline Nagyvárosi kormányzás nemzetközi dimenziói & Részvétel EGTC-ben \\
& Részvétel INTERREG projektben \\
\hline
\end{tabular}

Forrás: Saját szerkesztés

\section{Részvétel EGTC-ben}

Az Európai Unió regionális politikája a kezdetektől fókuszál az állam alatti területi egységek támogatására, azok határon túli együttműködéseinek erősítésére. A 2000-es évek közepére érett be a Régiók Bizottságának hosszas előkészítő munkája, mellyel az önkormányzatok és régiók határon túli együttműködéseinek jogi feltételrendszerét kívánták megteremteni. Az Európai Parlament és a Tanács 1082/2006/EK rendelete vezette be a közösségi jogba az európai területi együttműködési csoportosulás fogalmát (European Grouping of Territorial Cooperation, röviden EGTC, magyarul európai területi társulás, röviden ETT), a joganyagot 
később az Európai Parlament és a Tanács 1302/2013/EU rendeletében módosította, kiegészítve, pontosítva a korábbi rendelkezéseket. Az EGTC lényege, hogy az önkormányzatok, régiók és az államok határon átnyúló, transznacionális vagy régiók közötti együttműködést tudnak létrehozni más európai uniós tagállamok vagy harmadik államok jogalanyaival. Vagyis nemcsak az európai uniós tagállamok önkormányzatai működhetnek együtt, hanem a kooperációba a tagjelölt országok helyhatóságai is bevonhatók. Fontos hangsúlyozni, hogy az EGTC-k a szabályok értelmében jogi személyiséggel rendelkeznek, így az önkormányzatok és régiók ezen a szervezeten keresztül képesek európai uniós források lehívására. Mindez azt is jelenti, hogy az EGTC saját költségvetéssel, szervezettel és szerződő képességgel rendelkezik, ingó és ingatlan vagyonhoz is juthat. A jogi személyiség szempontjából döntő a székhely szerinti ország joga, ugyanis azt a jogrendszert kell alkalmazni az EGTC működése során.

Hazánk gyorsan, az első európai uniós joganyag megjelenését követő évben átültette a magyar jogrendbe a szabályozást (2007. évi XCIX. törvény az európai területi együttmúködési csoportosulásról), majd a szükséges módosításokat, kiegészítéseket is megtette a magyar jogszabályok rendszerében (2010. évi CXXVI. törvény, 2014. évi LXXV. törvény, 485/2017. (XII. 29.) Kormányrendelet). A hazai szabályozás értelmében az alábbi tevékenységek ellátásával kapcsolatban lehet EGTC-t alapítani: közlekedés, környezetvédelem, oktatás, nevelés, egészségügy, elsősegély, energiafelhasználás, innovációs eszközök, K+F, kultúra, munkahelyteremtés és -fejlesztés, szociális szolgáltatások, turizmus, sport, mezőgazdaság (egtc.kormany.hu 2018).

Az alábbi térképen azok az EGTC-k láthatók, melyek a magyar határ menti térségekben müködnek. Önmagában az a tény, hogy a lehetőség megteremtését követő egy évtizedben 24 ilyen területi együttmüködési szervezet jött létre, mutatja, hogy a határ menti területek érdeklődnek egymás iránt, megfigyelhető a határ menti kapcsolatok élénkülése. Az együttműködések két formáját különíthetjük el: egyrészt a határ menti megyei önkormányzatok együttműködésén alapuló EGTC-k, másrészt pedig a határ menti városok és települések részvételével működő együttmúködések. A vizsgálatba vont magyar nagyvárosok közül mindössze három (Győr, Pécs és Nyíregyháza) kapcsolódik EGTC-hez, míg Debrecen, Szeged és Miskolc nem tagja ilyen típusú együttműködésnek (2. ábra).

A Pannon EGTC 2010-ben jött létre pécsi székhellyel. A több, mint 60 tagot számláló EGTC három európai uniós tagállam területén működik, így magyar, horvát és szlovén résztvevőkkel bír (3. ábra). Azon ritka EGTC-k közé tartozik, melyek a megyei önkormányzatokat és a nagyvárosokat egy közös szervezetbe tömörítik. A tagok nagy része magyarországi település, illetve megye, így megtaláljuk Pécs mellett a térség megyei jogú városai közül Szekszárdot, Kaposvárt, Zalaegerszeget, több kisvárost és kistelepülést, Pécs, Tolna, Baranya és Zala megyék önkormányzatait, valamint a Pécsi Tudományegyetemet és a Duna-Dráva Nemzeti Parkot. Horvát részről a határ menti négy zsupánság (megye) mellett három te- 
2. ábra: A magyarországi EGTC-k

EGTCs in Hungary

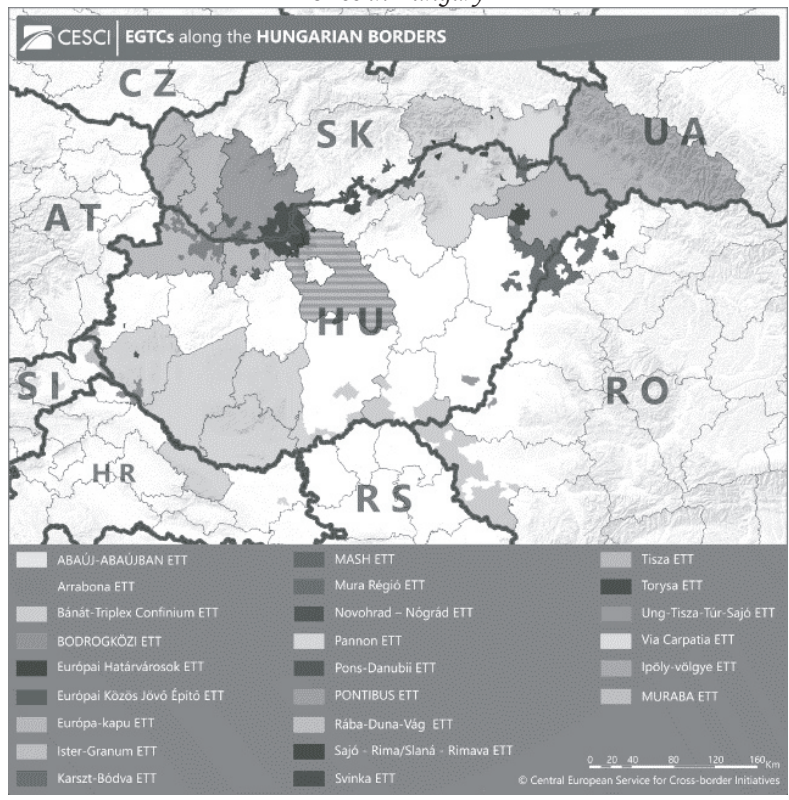

Forrás: egtc.kormany.hu/terkepek (2019)

lepülés csatlakozott az együttműködéshez, míg a szlovén oldalról szintén három település (köztük Lendva) tagja az EGTC-nek.

3. ábra: A Pannon EGTC területe Area of Pannon EGTC

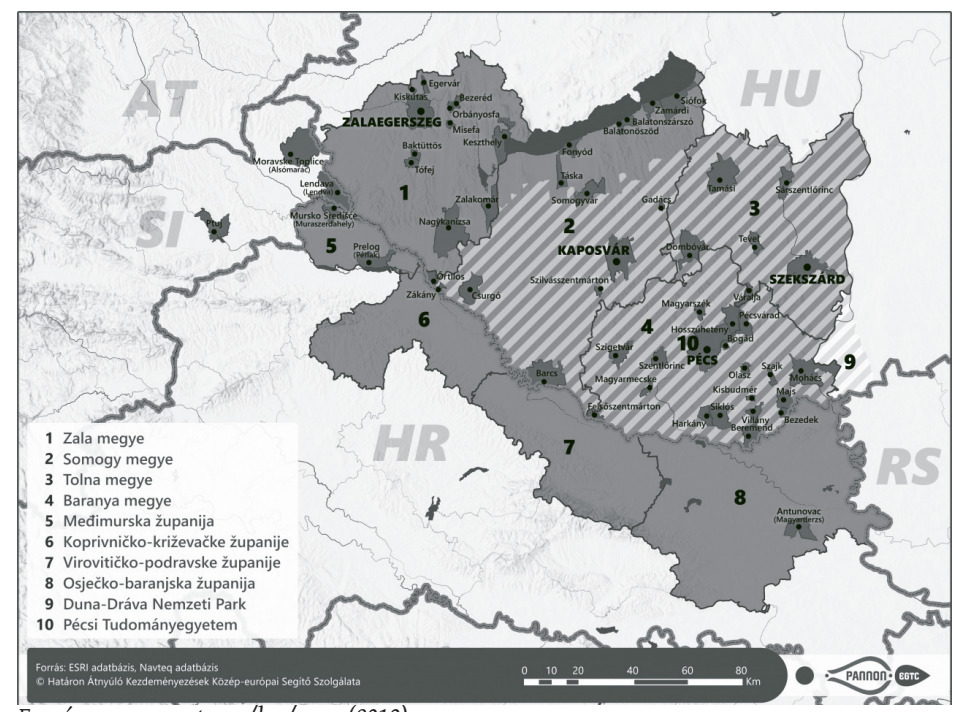

Forrás: pannonegtc.eu/hu/map (2019) 
A Pannon EGTC tevékenysége során folyamatosan kezdeményez, lehetőségeket biztosít a résztvevő települések vezetői, civil és gazdasági szervezetei számára, az elmúlt időszakban több közös projektet is végrehajtottak a határ menti kapcsolatok erősítése érdekében, jelenleg is részesei INTERREG, illetve egyéb futó projekteknek (lásd a későbbiekben). A Pécs környéki EGTC tehát láthatóan nagy számban tudott megszólítani környékbeli településeket, amelyek csatlakozásukkal a déli határtérségben zajló folyamatokba aktívan be tudnak kapcsolódni. Örömteli, hogy az önkormányzatok mellett az egyetem és a nemzeti park is csatlakozott az együttmüködéshez, ez unikális a vizsgált EGTC-k között. Véleményem szerint az EGTC súlyát nagyban tudná növelni, ha képes lenne megszólítani és integrálni a határ menti szlovén és horvát térségi funkcióval rendelkező városokat, így beemelve az együttműködésbe a Muraszombat-Varasd-Verőce-Eszék „tengelyt”.

2011-ben alakult meg Győrben az Arrabona EGTC. Már a névválasztás is utal a térség központjára, hiszen az alapítók (Győr, Mosonmagyaróvár, Dunaszerdahely, Somorja) Győr ókori római nevét választották az újonnan létrehozott együttműködés számára. Jelenleg közel 30 tagtelepüléssel bír a szervezet, mely hangsúlyozottan az egyes települések együttműködésére épít, annak nem tagjai egyik oldalról sem a megyei önkormányzatok. A csatlakozott települések Magyarországról és Szlovákiából, zömmel a Győr környéki térségből, a Szigetközből és a Csallóközből kerülnek ki (4. ábra).

Az Arrabona EGTC az alapítást követően egyrészt növelte tagtelepüléseinek számát, másrészt folyamatosan nyújtott be különböző, a tagtelepülések együttműködését elősegíteni kívánó pályázatokat. Az első évek pályázati sikertelensé-

4. ábra: Az Arrabona EGTC területe Area of Arrabona EGTC

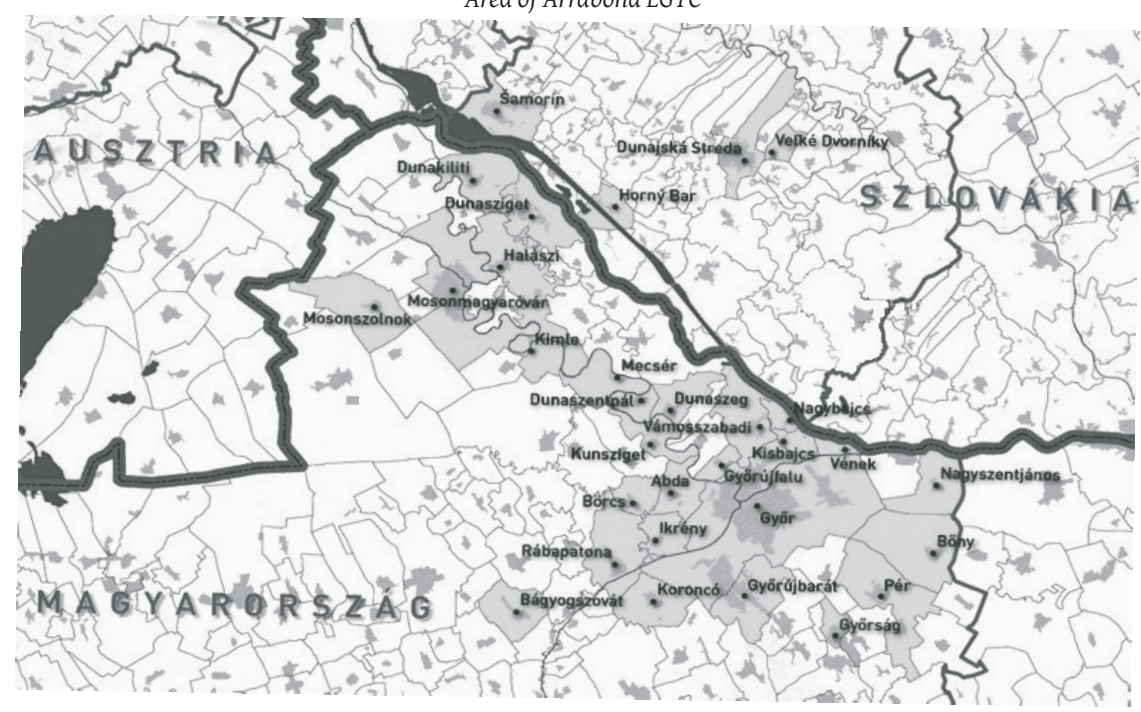

Forrás: arrabona.eu/index.html (2019) 
gével párhuzamosan az EGTC kiépítette projektmenedzsment-szolgáltató tevékenységét, így számos győri és más települések által elnyert projekt menedzsmentjét is elvégezte. Pályázatírói és projektszervezési feladatokat látott el pl. a győri ipari park iparvágány bővítésével, a Rábcatoroki kistérség LEADER projektjeivel, falubuszbeszerzési projektekkel stb. kapcsolatban. A későbbiekben látni fogjuk, hogy Győr - az Arrabona EGTC-n keresztüli - vezetésével jelenleg is folyamatban van két határ menti INTERREG projekt végrehajtása, mely növeli az intézményi kapcsolatok számát a régióban. Az Arrabona EGTC jövője szempontjából szintén fontos kérdés, hogy képes lesz-e növelni felvidéki tagtelepüléseinek számát, hiszen a határ túloldalán még bőven vannak kiaknázatlan területek. Egyelöre kérdéses, hogy ez mennyire lesz sikeres a jövőben, azt azonban érdemes hangsúlyozni, hogy az EGTC felismerte a további bővítés szükségességét: ennek érdekében 2018-ban megnyitotta irodáját Dunaszerdahelyen, amely kifejezetten a határon túli településekkel való intenzív kapcsolattartást és -építést szolgálja.

A harmadik érintett EGTC az Európai Határvárosok EGTC nevet viseli. Viszonylag új keletű együttműködésről van szó, hiszen 2014-ben alapította hazai részről Nyíregyháza, román oldalról pedig Szatmárnémeti. A taglétszám az alapítás óta nem bővült, jelenleg is a két alapító tag alkotja az együttműködést. A csoportosulás célja a határ menti fejlesztési programok kidolgozása és végrehajtása, lehetőség szerint európai uniós finanszírozás becsatornázásával. Az alapítás éve alapján feltételezhető, hogy a 2014-2020-as időszak pályázati forrásaira már pályázni kívántak a tagok. Nyertes pályázatról azonban nem tudunk, az együttmüködés honlapja más információkat nem nyújt. Az Európai Határvárosok EGTC-vel kapcsolatban mindenképp pozitív fejleményként értékelendo", hogy a határ menti két nagyváros annak megalapításáról határozott és célrendszerében a további együttműködést és közös térségfejlesztést határozta meg. Ahhoz azonban, hogy a kitűzött célokat el tudják érni, mindenképpen szükséges mind hazai, mind román oldalon megszólítani a vonzáskörzetükben lévő kisebb településeket, meggyőzni azokat a csatlakozás szükségességéről.

Győr és Pécs tehát a lehetőség megteremtését követően viszonylag gyorsan közreműködött a városrégiójában működő EGTC megalapításában, mindkét szervezet hosszú ideje működik, s az elmúlt években jelentősen tudta növelni tagjainak számát. Győr a térségét hangsúlyozottan Dunaszerdahely kiemelt partnerségével alakítja, Pécs esetében nincs ilyen meghatározó, határon túli szereplő, az együttműködésben ugyanakkor a hazai és a megyei önkormányzatok is részt vállalnak. Nyíregyháza viszonylag fiatal EGTC-vel rendelkezik, melyet Szatmárnémetivel közösen hozott létre (4. táblázat). A jövőben mindegyik érintett város esetében a partneri kapcsolatok szélesítése és mélyítése jelentheti a városrégió szintű kormányzási együttműködések erősítésének zálogát. A potenciális határon túli nagyvárosi partnerekkel rendelkező magyar nagyvárosok számára pedig különösen is ajánlott lenne ilyen típusú együttműködések kialakítása, a várostérségük határon átnyúló dimenziójának erősítése érdekében (pl. Debrecen-Nagyvárad, Szeged-Újvidék, Miskolc-Kassa relációk). 
4. táblázat: A magyar nagyvárosok részvétele az EGTC-kben The role of Hungarian big cities in EGTCS

\begin{tabular}{lll}
\multicolumn{1}{c}{ Gyor } & \multicolumn{1}{c}{ Ivyıregynıza } & \multicolumn{1}{c}{ recs } \\
\hline Arrabona EGTC & $\begin{array}{l}\text { Európai Határvárosok } \\
\text { EGTC }\end{array}$ & $\begin{array}{l}\text { Pannon } \\
\text { EGTC }\end{array}$ \\
2011 & 2014 & 2010 \\
Dunaszerdahely & Szatmárnémeti & - \\
Igen & Igen & Igen \\
28 & 2 & 66
\end{tabular}

Forrás: saját szerkesztés

\section{Részvétel INTERREG projektekben a 2014-2020-as időszakban}

Az Európai Unió regionális politikájának kipróbált eszközét képezik az INTERREG projektek. A jelenleg ötödik sorozatát élő program célja, hogy támogassa a különböző tagországok nemzeti, regionális és helyi szereplői közti közös akciók megvalósítását. A program háromféle interakciót támogat: a határ menti projektek keretében két-három ország határ menti térségei működnek együtt a határon átnyúló gazdasági és társadalmi kapcsolatok fejlesztése céljából. A transznacionális együttműködések az országos szintek feletti területi egységek kapcsolatainak létrejöttét támogatják, az európai térség területi integrációját segítik elő, míg az interregionális programok az egész Európai Unió területét lefedik, céljuk, hogy elősegítsék a résztvevők közti tapasztalatcserét, ráadásul az interregionális programokban Európai Unión kívüli országok is részt vehetnek (palyazat.gov.hu).

Az alábbiakban a hat nagyváros folyamatban lévő INTERREG pályázatainak elemzése következik. Vajon milyen témával foglalkoznak elsősorban ezek a projektek? Milyen hatással lehetnek a nagyvárosok határon átnyúló együttműködési kapcsolataira? Találunk-e példát kifejezetten a kormányzást elősegítő projektekre? Vezető vagy projektpartneri szerepet játszanak az egyes városok? A nagyvárosokhoz kapcsolódó INTERREG projektek összegyűjtésekor azokat a projekteket vettük figyelembe, melyekben az érintett város közvetlenül, az általa irányított EGTC-n vagy valamely meghatározó intézményén keresztül vesz részt (5. táblázat).

Győr esetében két, jelenleg is futó INTERREG projektet nevezhetünk meg, mindkettő a határ menti (magyar-szlovák) együttműködések erősítését tűzte ki célul. A vezető partner mindkét esetben az az Arrabona EGTC, mely győri székhellyel, aktív győri jelenléttel müködik, s több mint 30 határ menti települést foglal magába. A Builcogreen projekt a városüzemeltetési, városi szolgáltatások- 


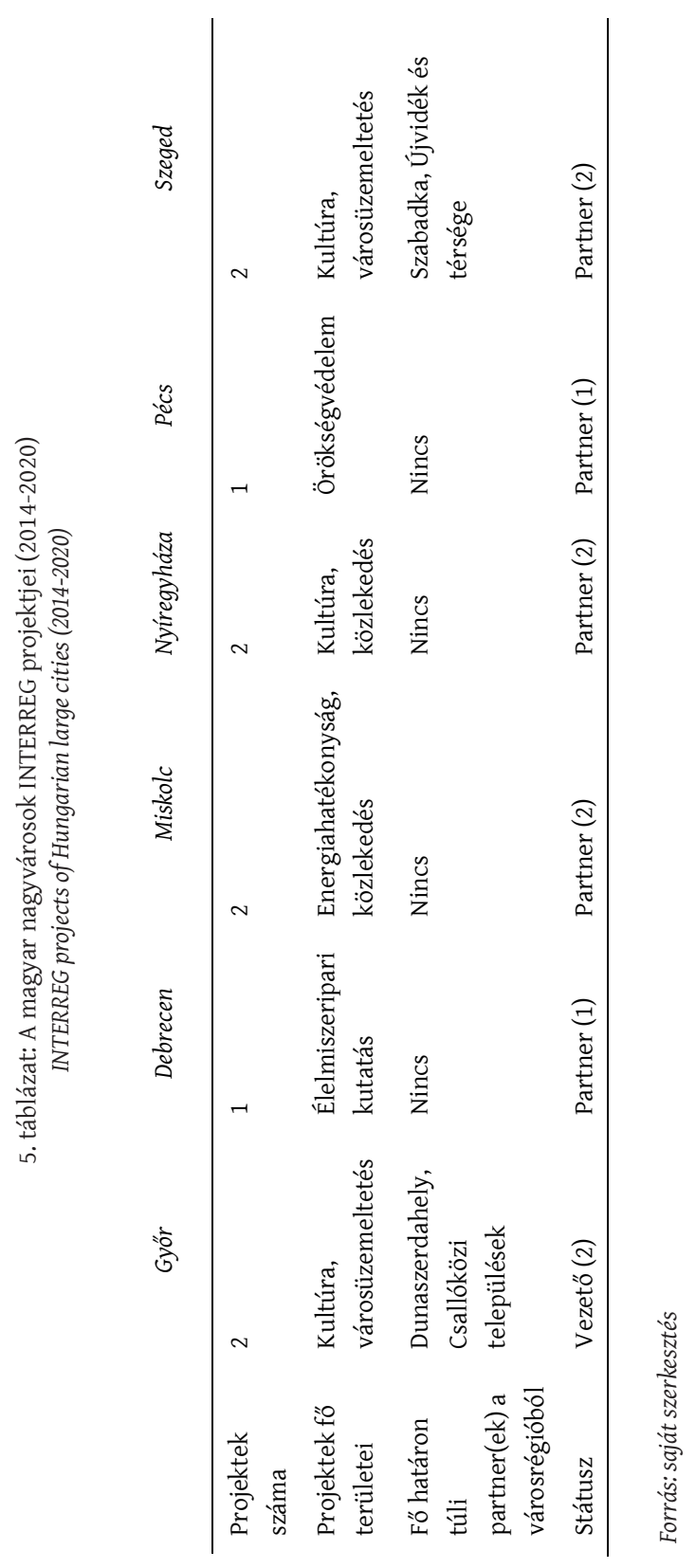


kal kapcsolatos tapasztalatok cseréjét, az erőforrások optimálisabb felhasználását szolgálja a határ menti térségben. A projekt keretében négy település, Győr, Mosonmagyaróvár, Dunaszerdahely és Somorja együttmüködése a meghatározó, az önkormányzatok mellett a helyi szolgáltató cégek is fontos szerepet játszanak az együttműködésben. A kérdéses területen folyamatos interakciók alakulnak ki a résztvevő szervezetek képviselői között, céljuk pedig végső soron a városi közszolgáltatások optimálisabb szervezése a határ menti térségben, vagyis a szervezettebb, gazdaságosabb üzemeltetés modelljének kialakítása a városüzemeltetés területén. A Cultacross projekt elsősorban a térség közös kulturális pozícionálását hivatott segíteni, legfőképpen Győr és Dunaszerdahely együttműködésével. A rendszeres interakciók a résztvevő települések önkormányzatai és kulturális szakemberei között valósulnak meg, fó céljuk pedig a közös megjelenéssel és közös rendezvények szervezésével a látogatószám emelése, a turisztikai bevételek növelésével párhuzamosan. A két győri projekt esetén tehát Győr vezető szerepét érdemes hangsúlyoznunk, a projektek révén a Szigetköz és a Csallóköz településeinek vezetői, városüzemeltetési, illetve kulturális szakemberei közti kapcsolatok egyre rendszeresebbé válnak, a várostérségben pedig optimálisabb szervezési rendszerek alakulhatnak ki, melyek végső soron Győr és vonzáskörzete gazdasági mutatóit is javíthatják. Az ismertetett projektek alapján Győr határon túli vonzáskörzetének fö eleme, s egyben a város fontos partnere Dunaszerdahely (arrabona.eu/builcogreen 2019, arrabona.eu/cultacross 2019).

Szegeden szintén két futó INTERREG pályázatot találtunk, Győrhöz hasonlóan a határ menti együttműködések kategóriájában. A kulturális FILMY projekt célja, hogy a térségben intézményesített együttműködés jöjjön létre a filmmüvészet területén, mely közös kulturális és oktatási programokat eredményez. A projekt elsősorban Szabadka és Szeged filmes és kulturális szervezeteinek együttműködésére épül. Az Újvidéki Egyetem vezetésével és Szeged aktív közreműködésével valósul meg a másik vizsgált projekt, mely az intenzív csapadékvíz és villámárvíz monitoring-, előrejelző- és online tájékoztató-, valamint figyelmeztető rendszer létrehozására irányul a magyar-szerb határ menti régió városaiban. Szeged projektjei tehát kulturális és városüzemeltetési fókuszúak, a város pedig Szabadka és Újvidék felé fejti ki hatását. Fontos hangsúlyozni, hogy az előcsatlakozási alapokból finanszírozott projektek Szerbia európai uniós csatlakozásának támogatására is szolgálnak (interreg-ipa-husrb.com/hu/projectek 2019).

A vizsgált nagyvárosok INTERREG projektjeivel kapcsolatos adatgyüjtés során tehát két város esetében került feltárásra határ menti együttmüködés keretében megvalósuló projekt. A másik négy nagyváros is résztvevője INTERREG projektnek, azonban nem határ menti, hanem transznacionális együttműködésekben érdekeltek (pl. Duna-projektek), melyek közvetlen vonzáskörzetükre nem hatnak.

Érdekes, hogy a két határ menti együttműködésben érdekelt város (Győr és Szeged) nem tud felmutatni interregionális vagy transznacionális projektben való részvételt, holott ez jól kiegészíthetné határ menti hatásukat a nemzetközi ki- 
sugárzás lehetőségével. A vizsgált projektek keretében a hat nagyvárosból egyedül Győr vesz részt vezetőként a projektekben (egyszerre kettőben is), a többi város partneri státuszban van. Ennek azért is lehet jelentősége, mert egy ilyen projekt irányításával a város a térségszervezés fontos mozgatójává léphet elő, határon túli térségének szereplőit koordinálhatja, irányíthatja, s ezáltal erősítheti azok városhoz való kötődését. Ráadásul ezek a projektek nem csak a városhatáron túli kormányzási dimenziót erősíthetik, hanem az új szereplők bevonására is lehetőséget nyújthatnak (egyetemek, civil szervezetek, szolgáltató cégek stb.).

A vizsgált nagyvárosokat érintő INTERREG projektek feltérképezése megfelelő alkalmat teremt számunkra, hogy megnézzük, vajon a nagyvárosi önkormányzatok milyen más szervezetekkel működnek együtt, s vonják be azokat a nagyvárosi kormányzás folyamatába. Az 1. ábrán látható, hogy a nagyváros önkormányzata optimális esetben bevonja a civil, a gazdasági szféra, a helyi kutatás-fejlesztési kör szereplőit, továbbá az állami szerveket annak érdekében, hogy minél jobban bővítse a nagyvárosi kormányzásba bevont érintettek körét. A 6. táblázatban összegezzük, hogy ennek mennyiben felelnek meg az általunk vizsgált nagyvárosok az INTERREG projektjeik összetétele alapján. A táblázatban csak azokat a projektpartnereket tüntettük fel, melyek nem maguk az érintett önkormányzatok, illetve az önkormányzatok által múködtetett intézmények, vállalkozások (pl. önkormányzati fenntartású színházak, mozik, kulturális intézmények, helyi közszolgáltató vállalatok).

6. táblázat: A nagyvárosok projektpartnerei The project partners of large cities

\begin{tabular}{|c|c|c|}
\hline varus & rтиеке & гтојекциитьнетек \\
\hline \multirow[t]{2}{*}{ Győr } & Cultacross & Magántulajdonú kulturális vállalkozás \\
\hline & Builcogreen & Nincs \\
\hline Debrecen & String & $\begin{array}{l}\text { Agrár-érdekképviseleti szervezet, élelmiszeripari vállalkozások } \\
\text { szervezetei, klaszterei, egyetemek, kutatóintézetek }\end{array}$ \\
\hline \multirow[t]{2}{*}{ Miskolc } & REBUS & $\begin{array}{l}\text { Energiaügynökség, regionális fejlesztési ügynökségek, } \\
\text { innovációs központ }\end{array}$ \\
\hline & TRAM & Fejlesztési ügynökség \\
\hline \multirow[t]{2}{*}{ Nyíregyháza } & CBCMC & Hírközlési szakmai szervezetek \\
\hline & CITYWALK & $\begin{array}{l}\text { Kutatóközpont, innovációs egyesület, egyetemek, regionális } \\
\text { fejlesztési ügynökségek }\end{array}$ \\
\hline Pécs & SHARE & Egyetemek, regionális fejlesztési ügynökségek \\
\hline \multirow[t]{2}{*}{ Szeged } & FILMY & Nincs \\
\hline & Villámárvíz & Egyetemek \\
\hline
\end{tabular}

Forrás: saját szerkesztés az érintett városok projektjeiról készitett adatbázis alapján 
A felsorolás alapján látható, hogy a nagyvárosok széles körben vonnak be tőlük független projektpartnereket is Interreg projektjeik megvalósításába. Elmondható, hogy a K+F-intézmények (egyetemek, kutatóközpontok), továbbá a regionális fejlesztési ügynökségek (többnyire állami szervként) gyakori résztvevői ezen együttműködéseknek, melyet indokolhat az általuk birtokolt speciális szaktudás. A gazdasági szereplők zömmel valamilyen érdekképviseleti szervezeten, klaszteren keresztül kapcsolódnak be az egyes projektek megvalósításába, bár láthatunk példát arra is, hogy valamely gazdasági szereplő közvetlenül projektpartnerként jelenik meg. Az egyes projektek profiljába illeszkedő civil szervezetek elvétve kerülnek bevonásra. Itt szükséges ugyanakkor megjegyezni, hogy a projektpartneri státuszú együttműködőkön túl az egyes projektekbe sok esetben számtalan más szervezet tud bekapcsolódni a megvalósult rendezvényeken, képzéseken, disszeminációs tevékenységen keresztül.

\section{Összegzés, kitekintés}

A tanulmányban feltárásra került a határ menti magyar nagyvárosok kormányzásának fő intézményi keretei, továbbá a kapcsolódó projektszintű együttműködések. Elmondható, hogy az Európai Unió különböző eszközökkel ösztönzi a határ menti térségekben lévő nagyvárosok kormányzási tevékenységét, így megteremtette a szükséges jogi kereteket, továbbá különböző pályázati lehetőségeken keresztül pénzügyi ösztönzőket is biztosít az együttműködések katalizálása érdekében. A magyarországi jogi szabályozás is lekövette az európai uniós keretek kialakítását, így ma sem jogi, sem szabályozási akadálya nincs a határ menti térségekben lévő magyar nagyvárosok kormányzását erősítő szervezetek létrehozásának, projektszintű együttmüködések kialakításának.

Az első két kutatási kérdésre, miszerint léteznek-e formalizált intézményi keretei a határ menti magyar nagyvárosok kormányázásának, továbbá együttműködnek-e a intézményesített módon a magyar nagyvárosok határon túli vonzáskörzetük településeivel, szervezeteivel, a következő választ adhatjuk: noha megfelelő feltételrendszerek alakultak ki, nagyvárosaink többsége mégsem él a lehetőségekkel. A vizsgálat bizonyította, hogy az első indikátorként kiválasztott EGTC tagság mindössze a vizsgált nagyvárosok felében áll fenn, ezek közül valódi aktivitást mindössze két nagyváros (Pécs és Győr) mutat. Pécs jó példával jár elöl a nem önkormányzati szereplők bevonását illetően is. Noha Magyarországon 24 EGTC müködik, a vizsgált nagyvárosokat mindössze három érinti. Érdemes hangsúlyozni, hogy a kimaradó nagyvárosok (Debrecen, Szeged, Miskolc) mindegyike rendelkezik a határ túloldalán olyan potenciális partnerrel, mellyel összefogva képes lenne formalizált intézményi keretet létrehozni a határtérségben lévő szereplők bevonása, együttműködések kialakítása érdekében. 
A tanulmány elején feltett harmadik és negyedik kutatási kérdésre (léteznek-e olyan projektjellegű együttműködések, melyek erősítik a határ menti nagyvárosok kormányzási tevékenységét, továbbá milyen mértékben vonják be ezekbe a nem kormányzati szereplőket?) a projektalapú együttműködések vizsgálatának eredményei adnak választ. A kép ez esetben kedvezőbbnek tűnik, hiszen a hat nagyváros valamilyen módon összesen tíz INTERREG projektben vesz részt a jelenleg futó 2014-2020-as időszakban, ami reményt jelent arra nézve, hogy a nagyvárosok affinitással rendelkeznek más városokkal, területi egységekkel történő nemzetközi együttműködések lebonyolítására. Árnyalja a képet ugyanakkor, hogy ezek közül mindössze három olyan projekt van, mely határ menti térségben valósul meg, s azok két nagyvároshoz (Győr és Szeged) kötődnek. INTERREG projektben vezető szerepet kizárólag Győr tölt be, a kisalföldi megyeszékhely két projekt esetében is ilyen minőséggel rendelkezik. A projektpartnerek listája ugyanakkor változatos: ezekbe az együttmüködésekbe a nagyvárosok bevonják a gazdasági szféra képviselőit, a K+F-szervezeteket, az állami szerveket, és mérsékelt aktivitással ugyan, de a civil szféra szereplői is feltünnek.

Összességében elmondható, hogy határ menti kormányzási struktúrák kiépítésében a vizsgált hat nagyvárosból kettő (Miskolc, Debrecen) semmilyen aktivitást nem mutat a meghatározott indikátorok alapján, Nyíregyháza esetében a formális keret ugyan létrejött, de valódi aktivitás nem tapasztalható. A nagyvárosok vizsgálata alapján Győr emelkedik ki, hiszen formális együttműködést irányít, továbbá a határ menti térségben több projektben is irányító szerepet tölt be (7. táblázat).

Véleményem szerint a jövőben a magyar nagyvárosoknak nagyobb hangsúlyt szükséges helyezniük határ menti kormányzásuk erősítésére, természetes vonzáskörzetük szervezésére, koordinálására. Mivel a jogi feltételrendszer biztosított, továbbá léteznek anyagi ösztönzők is, adott a lehetőség nagyvárosok számára, hogy akár formális együttmúködés, akár projektalapú kooperáció keretében bevonják vonzáskörzetük településeit és szereplőit a térség kormányzásába. Mindezek megvalósításához a teljesség igénye nélkül az alábbi intézkedések megtétele erősítheti a határ menti magyar nagyvárosok kormányzását:

\begin{tabular}{|c|c|c|c|c|c|c|}
\hline & \multicolumn{4}{|c|}{$\begin{array}{c}\text { 7. táblázat: A vizsgálat eredményeinek összegzése } \\
\text { Summary of the results }\end{array}$} & \multirow[b]{2}{*}{ Pécs } & \multirow[b]{2}{*}{ Szeged } \\
\hline & Györ & Debrecen & Miskolc & Nyíregyháza & & \\
\hline EGTC tagság & $\mathrm{X}$ & & & $\mathrm{X}$ & $\mathrm{X}$ & \\
\hline $\begin{array}{l}\text { INTERREG futó } \\
\text { határ menti projekt }\end{array}$ & $\mathrm{X}$ & & & & & $\mathrm{X}$ \\
\hline $\begin{array}{l}\text { INTERREG futó } \\
\text { projekt }\end{array}$ & $\mathrm{X}$ & $\mathrm{X}$ & $\mathrm{X}$ & $\mathrm{X}$ & $\mathrm{X}$ & $\mathrm{X}$ \\
\hline
\end{tabular}


- Kezdeményező, proaktív hozzáállás és attitűd a nagyváros önkormányzata részéről;

- Sokszereplős, működő EGTC-k létrehozása a határtérségekben, a határon túli kiemelt partnerek azonosítása és bevonása, a határ menti térség közös fejlesztési igényeinek azonosítása;

- Az EGTC-k tagságának szélesítése, az önkormányzati szereplők mellett a térségi felsőoktatási intézmények, civil szervezetek, gazdasági érdekképviseleti szervek stb. bevonása;

- Az európai uniós források feltérképezése és lehívása az INTERREG és más pályázati lehetőségeken keresztül, olyan projektek előkészítése és végrehajtása, melyek révén sürűsödnek a határ két oldalán lévő szereplők egymás közti interakciói.

- Felkészülés a 2021-2027-es európai uniós költségvetési időszak határ menti együttmúködést támogató forrásainak lehívására.

\section{Jegyzetek}

1 Magyarországon még Kecskemét és Székesfehérvár rendelkezik 100000 főt meghaladó, illetve megközelítő lakosságszámmal, ezek azonban földrajzi helyzetükből fakadóan nem rendelkeznek határon átnyúló vonzáskörzettel.

2 Végül a győztes a hazai viszonylatban középvárosnak számító Veszprém lett, így ez a város viseli 2023-ban az Európa Kulturális fővárosa címet.

\section{Irodalomjegyzék}

Bajmócy Z. (2011): Bevezetés a helyi gazdaságfejlesztésbe. JATEPress, Szeged

Balázs I. (2014): Franciaország térszerkezetének átalakítása és a városi térségek kezelésének eszközrendszere a várospolitika keretei között. In: Hardi T., Somlyódyné Pfeil E. (szerk.): Városfejlődési trendek és állami szerepek. Universitas-Győr Nonprofit Kft., Győr, 112-133.

Carayannis, E. G.. Barth, T. D., Campbell, D. F. J. (2012): The quintuple helix innovation model: Global warming as a challenge and driver for innovation. Journal of Innovation and Entrepreneurship, 2., 1-12. http://doi.org/dz5p

Carayannis, E. G., Campbell, D. F. J. (2012): Mode 3 knowledge production in quadruple helix innovation systems. Springer Briefs in Business, 7., 1-63. http://doi.org/d5fjdh

Enyedi Gy. (2012): Városi világ. Akadémiai Kiadó, Budapest

Etzkowitz, H., Leydesdorff, L. (1996): The triple helix of university-industry-government relations: A laboratory for knowledge based economic development. EASST Review, 1., 11-19.

Etzkowitz, H., Leydesdorff, L. (2000): The dynamics of innovation: From national systems and „Mode 2" to a Triple Helix of university-industry-government relations. Research Policy, 29., 109-123. http://doi.org/ckvg76

Faragó L. (2006): A városokra alapozott területpolitika koncepcionális megalapozása. Tér és Társadalom, 2., 83-102. http://doi.org/czm7

Feiock, R. C. (2004): Introduction: Regionalism and institutional collective action. In: Feiock, R. C. (ed.): Metropolitan Governance: Conflict, Competition and Cooperation. Georgetown University Press, Washington D.C., 3-16. 
Fekete D. (2017a): A Modern Városok Program elemzési lehetőségei. Polgári Szemle, 1-3., 94-105. http://doi.org/czk9

Fekete D. (2017b): Az Arrabona EGTC mint a győri nagyvárosi gazdasági kormányzás egyik lehetséges szervezeti kerete. In: Széchenyi István Egyetem (szerk.): Új Nemzeti Kiválóság Program 2016/17 Tanulmánykötet. Széchenyi István Egyetem, Győr, 117-125.

Fekete D. (2017c): Európai járműipari térségek gazdasági kormányzási modelljei. Tér és Társadalom, 3., 125-142. http://doi.org/czm8

Fekete D. (2017d): Nagyvárosi régiók gazdasági kormányzása. Ujj megközelitések európai járműipari központok elemzésével. Doktori értekezés. Széchenyi István Egyetem Regionális- és Gazdaságtudományi Doktori iskola, Győr

Heintel, M., Weixlbaumer, N., Debre, B. (2015): Védett területek mint a határon átnyúló együttmüködés tényezői? Reflexiók az osztrák-magyar határ mentén lebonyolított ETE-projekt tapasztalatai alapján. Tér és Társadalom, 4., 117-138. http://doi.org/dz5q

Horváth M. T. (2015): Megszabva. Városi kormányzás másutt és itthon. Tér és Társadalom, 2., 43-66. http://doi.org/b96q

Horváth M. T.(2002): Helyi közszolgáltatások szervezése. Dialóg Campus Kiadó, Budapest, Pécs

Lefèvre, C. (1998): Metropolitan government and governance in western countries: A critical review. International Journal of Urban and Regional Research, 1., 9-25. http://doi.org/c4km73

Mezei, I., Tóth, P. (2008): A települési és területi önkormányzatok kapcsolatai a magyar-szlovák határ mentén. Tér és Társadalom, 3., 51-80. http://doi.org/dz5r

Moon, M. J. (2001): Cultural governance. A comparative study of three cultural districts. Administration \& Society, 4., 432-454. http://doi.org/dw6qh7

Nelson, A. C., Foster K.A. (1999): Metropolitan governance structure and income growth. Journal of Urban Affairs, 3., 309-324. http://doi.org/drj4mm

Oakerson, R. J. (2004): The study of metropolitan governance. In: Feiock, R. C. (ed.): Metropolitan Governance: Conflict, Competition and Cooperation. Georgetown University Press, Washington D.C., $17-45$.

Pálné Kovács I. (1999): Regionális politika és közigazgatás. Dialóg Campus Kiadó, Budapest, Pécs

Pálné Kovács I. (2008): Az új várospolitika kormányzási filozófiája. Tér és Társadalom, 1., 45-57. http:// doi.org/c2bn

Pálné Kovács I. (2010): Városi terek kormányzása és a városi rezsimek. Egy induló kutatás margójára. Tér és Társadalom, 4., 3-27. http://doi.org/cznb

Pálné Kovács I. (2015): Helyi tudás, helyi kormányzás, helyi fejlesztés. Magyar Tudomány, 2., 150-158.

Rechnitzer J. (2019): Nagyvárosok a magyar területi politikában és fejlesztésben a rendszerváltozástól napjainkig. Tér és Társadalom, 1., 3-26. http://doi.org/c85m

Schmitt, T. (2011): Cultural Governance as a conceptual framework. MMG Working Paper, 11-02, Göttingen

Somlyódyné Pfeil E. (2008): A városi térségek a közigazgatási struktúra és a „governance” keresztmetszetében. Tér és Társadalom, 1., 27-43. http://doi.org/czmb

Somlyódyné Pfeil E. (2011): Az agglomerációk jelentőségének változása az államszervezés és a városi kormányzás szempontjából. Tér és Társadalom, 3., 27-59. http://doi.org/cznc

Stone, C. (1989): Regime Politics: Governing Atlanta, 1946-1988. University Press of Kansas, Lawrence

Stone, C., Sanders, H. T. (1987): The Politics of Urban Development. University Press of Kansas, Lawrence

Sybert, R. (1999): Models of regional governance. In: Kemp, L. R. (ed.): Forms of Local Governance: Handbook on City, County and Regional Option. McFarland Company Inc., Publisher, Jefferson, North Carolina, 172-185.

Vas Zs. (2012): Tudásalapú gazdaság és társadalom kiteljesedése. A Triple Helix továbbgondolása - a Quadruple és Quintuple Helix. In: Rechnitzer J., Rácz Sz. (szerk.): Dialógus a regionális tudományról. Széchenyi István Egyetem Regionális- és Gazdaságtudományi Doktori Iskola - Magyar Regionális Tudományi Társaság, Pécs, 198-207. 


\section{Dokumentumok, honlapok}

2007. évi XCIX. törvény az európai területi együttműködési csoportosulásról. Magyar Közlöny, 2007., https://mkogy.jogtar.hu/jogszabaly?docid=a0700099.TV

2010. évi CXXVI. törvény a fóvárosi és megyei kormányhivatalokról, valamint a fóvárosi és megyei kormányhivatalok kialakításával és a területi integrációval összefüggő törvénymódosításokról, Magyar Közlöny, 2010., https://net.jogtar.hu/jogszabaly?docid=A1000126.TV

2014. évi LXXV. törvény az európai területi társulásról. Magyar Közlöny, 2014. 168. szám, http:// egtc.kormany.hu/download/0/22/d0000/Magyar\%20K\%C3\%B6zl\%C3\%B6ny.pdf

A Kormány 485/2017. (XII. 29.) Korm. rendelete az európai területi társulással kapcsolatos jóváhagyási és nyilvántartásba vételi eljárás részletes szabályairól. Magyar Közlöny, 2017. 231. szám, http://www.kozlonyok.hu/nkonline/MKPDF/hiteles/MK17231.pdf

Az Európai Parlament és a Tanács 1082/2006/EK rendelete (2006. július 5.) az európai területi együttmúködési csoportosulásról. Az Európai Unió Hivatalos Lapja, 2006. https://eur-lex.europa.eu/legal-content/HU/TXT/PDF/?uri=CELEX:32006R1082\&from=HU

Az Európai Parlament és a Tanács 1302/2013/EU rendelete (2013. december 17.) az európai területi együttmúködési csoportosulásról szóló 1082/2006/EK rendeletnek a csoportosulások létrehozásának és múködésének egyértelművé tétele, egyszerüsítése és javítása tekintetében történő módosításáról. Az Európai Unió Hivatalos Lapja, 2013. https://portal.cor.europa.eu/egtc/Legalframework/Documents/HU_revision.pdf

egtc.kormany.hu (2018): Mi az az ETT (EGTC)? http://egtc.kormany.hu/mi-az-az-ett-egtc

http://egtc.kormany.hu/terkepek

http://www.arrabona.eu/cultacross.html

http://www.arrabona.eu/index.html

http://www.arrabona.eu/builcogreen

http://www.terport.hu

http://www.interreg-danube.eu/approved-projects/ACCELERATOR

http://www.interreg-danube.eu/approved-projects/agrigo4cities

http://www.interreg-danube.eu/approved-projects/citywalk

http://www.interregeurope.eu/crehub/

http://www.interreg-ipa-husrb.com/hu/projectek/

http://www.nyir-szat.eu/egtc-ett/

http://www.skhu.eu/tamogatott-projektek/cross-border-conscious-media-consumption

https://www.interreg-central.eu/Content.Node/SlowFood-CE.html

https://www.interregeurope.eu/rebus/

https://www.interregeurope.eu/share/

https://www.interregeurope.eu/string/

https://www.interregeurope.eu/tram

https://www.pannonegtc.eu/hu/map

http://palyazat.gov.hu

United Nations (2016): Demographic Yearbook. United Nations, New York 